\title{
Publisher Correction: Ciliary beating patterns map onto a low-dimensional behavioural space
}

Veikko F. Geyer (D), Jonathon Howard (D) and Pablo Sartori (D)

Correction to: Nature Physics https://doi.org/10.1038/s41567-021-01446-2, published online 10 January 2022.

In the version of this article initially published, in Fig. 2d, the boxes above 'Ficoll 400 (\%)' should have been labelled 1, 5, and 10 instead of 10,5 and 1 .

In the 'Data availability' section, the URL for Dryad should have been https://doi.org/10.5061/dryad.0gb5mkm2j.

In Equation 4, a minus sign preceding the right-hand term was missing, while in the fourth line of the description of Equation 4, subscript b's were missing. The term should be “ $\chi_{b}^{\prime}+\chi^{\prime \prime}{ }_{b}$ ".

The errors have been corrected in the HTML and PDF versions of the article. Open Access This article is licensed under a Creative Commons Attribution 4.0 International License, which permits use, sharing, adaptation, distribution and
reproduction in any medium or format, as long as you give appropriate credit to the original author(s) and the source, provide a link to the Creative Commons
license, and indicate if changes were made. The images or other third party material in this article are included in the article's Creative Commons license, unless
indicated otherwise in a credit line to the material. If material is not included in the article's Creative Commons license and your intended use is not permitted by statutory
regulation or exceeds the permitted use, you will need to obtain permission directly from the copyright holder. To view a copy of this license, visit http://creativecommons.org/
licenses/by/4.0\%.

Published online: 23 February 2022

https://doi.org/10.1038/s41567-022-01552-9

(C) The Author(s) 2022 